\title{
Technology in ELT: English Teachers Investigate Animoto and Fotobabble
}

\author{
Abdullah Coşkun $^{1} \&$ Zoe Marlowe ${ }^{2}$ \\ ${ }^{1}$ School of Foreign Languages, Abant Izzet Baysal University, Bolu \\ ${ }^{2}$ School of Foreign Languages, Uskudar University, Istanbul \\ Correspondence: Abdullah Coşkun, School of Foreign Languages, Abant Izzet Baysal University, Bolu, Turkey. Tel: \\ 90-374-254-1000/2833. E-mail: coskun_a@ibu.edu.tr
}

Received: July 12, 2015

doi: 10.5430/ijhe.v4n3p119
Accepted: August 6, 2015

Online Published: August 7, 2015

URL: http://dx.doi.org/10.5430/ijhe.v4n3p119

\begin{abstract}
Because of being socially interactive, portable and multimodal, the Internet has had an impact on the field of foreign language education (Warschauer, 2001), and Web 2.0 tools have become integral parts of our everyday teaching. Thus, the aims of this study are twofold: On the one hand, it aims to introduce Animoto and Fotobabble as free Web 2.0 tools that can easily be adapted for English language teaching (ELT) purposes. Throughout the paper, the use of Animoto and Fotobabble in ELT is illustrated through sample activities incorporating these tools. On the other hand, the study also has the objective to reveal the attitudes of twelve university level English as a Foreign Language (EFL) instructors towards the use of these tools in ELT. To collect data regarding their attitudes, the participants were distributed via e-mail an informative document including an introduction to these tools, tutorials on how these tools work and sample Animoto and Fotobabble slides. They were then asked to write their reflections on whether these platforms would be good for learning/teaching English and what possibilities or activities English teachers could use them for. The collected qualitative data was analyzed by means of content analysis, and it was revealed that the study participants mostly held positive attitudes towards the use of these platforms in ELT, and could think of teaching activities incorporating these platforms. Also, it was found that although the majority gave positive comments, there were a few instructors sharing their concerns about their application in ELT. It is believed that such studies dealing with the use of new technologies in ELT are likely to lead to a more effective English learning/teaching process.
\end{abstract}

Keywords: English Language Teaching, Animoto, Fotobabble

\section{Introduction}

The idea of teaching with technology has gained more than just a modest fan base in this age when our students are from an era whose homes have had at least one computer, plus other electronic technologies in it since before they were born. As rightly argued by Kern (2006), technological tools such as instant messaging, chat rooms, Usenet groups, MOOs, blogs and wikis paved the way for new ways of teaching and learning. It is not any wonder then, that instructors are challenged with attempting to teach primarily from a textbook in an era dominated by electronic media which today's children known as 'digital natives' (Prensky, 2001) are dependent on. Nor does this challenge limit itself to the conventional classroom teacher of the general or specialized education subjects taught in universities; contrarily, subjects such as English as a Foreign Language (EFL) demand a paradigm shift in the way they are taught as well, and technology may just be the hidden treasure needed to facilitate learning as well as forming a positive connection between the teacher and students in the ELT classroom. To underline the importance of the use of technology to teach or to learn a foreign language, Hubbard $(2009$, p. 1) states: "...as computers have come more a part of our everyday lives - and permeated other areas of education - the question is no longer whether to use computers but how."

As argued by Shyamlee and Phil (2012), traditional ELT has been drastically altered due to the emergence of technology, which provides innumerable options for teachers to make teaching more interesting and engaging for their students. They claim that this also increases the productivity of teaching English, in essence providing evidence that technology is greatly assisting not only linguistic, but also social change.

EFL teachers desperately need to find novel and unique ways to deliver lessons (Morgan, 2008) which may garner a more positive response from students who seem largely distracted from, or bored with the usual language 
book-driven curriculum. The innovative EFL teacher searches for interesting and engaging ways to teach the language course materials, including the use of technology, as in specific tools found on the Internet which can be utilized by both the teacher and students.

Recent developments in Internet-based teaching and learning tools have resulted in technology becoming much easier to use, removing the 'fear factor' from experimenting with these types of digital products. Web 2.0 tools, among other web-based programs, are highly accessible and remarkably easy to use (Light \& Polin, 2010), making new methodologies in teaching EFL user-friendly enough for teachers to augment their curriculum in ways which provide positive results, as well as giving rise to the endless possibilities digital technology can provide in regard to the way students learn a foreign language. According to Shyamlee and Phil (2012), there is a need for the use of technology while teaching English because technology raises students' interest, their communication capacity, the effects of teaching, the interaction between the teacher and the student, and it paves the way for a flexible course content appealing to both visual and auditory learners and a proper context to teach the language.

It is argued that teachers' attitudes towards the integration of technology into the EFL classroom determine the degree and level of success of technology use in the classroom; in addition, their positive beliefs about a technological tool generally result in the successful implementation of this tool (Sepehr \& Harris, 1995; O'Conner \& Gatton, 2003; Handal, 2004; Albirini, 2006). Thus, this study focuses on two Web 2.0 tools (i.e., Animoto and Fotobabble) that can be used for ELT purposes, and more specifically the attitudes of university EFL teachers towards these tools are investigated. Animoto and Fotobabble are two examples of online digital technology tools, and these tools are easily adaptable to any EFL teaching scenario to assist the students in learning the target language in creative and fun ways. Both programs are Internet-based and housed, meaning there is no software to download, and everything can be accomplished with relatively little technical knowledge other than that of being able to upload image files from the teachers' computer (or any computer), type a few lines of text into an appropriate text receptacle, and in the case of Fotobabble, speak into the computer microphone and create a simple, one-minute voice recording.

After a review of Animoto and Fotobabble and an illustration of how they could possibly be used to teach EFL through suggested activities; the literature review related to the possible advantages Web 2.0 tools offer to the EFL classroom and to attitudes towards different Web 2.0 tools is presented. Then, the methodology of the study and the analysis of English teachers' reflections about these two tools are discussed by referring to their comments.

\subsection{Animoto}

Animoto (https://animoto.com/) is an online multimedia video presentation program which is very simple to operate. One signs up for a free account (which is upgradeable if desired) and then begins the process of designing a presentation similar to how you would create a PowerPoint or Prezi presentation. This program is more powerful in the way that the creator has an opportunity to choose animated, pre-made templates and can also choose music for their video presentation. The presentation is graphic and text driven, and can include many of the student's uploaded photographs. The uses for this tool are numerous, and depend upon the imagination and creativity of the user. As pointed out by İrgin and Turgut (2009), Animoto helps students not only to make connections, but also to make meaning, which in turn gives greater depth to their individual learning processes; in addition, the implications of Animoto broaden as students and teachers are able to take advantage of this and many other web-based instructional tools.

Teachers can create viable EFL assignments using Animoto, giving the students a few simple guidelines for their production, such as asking for a specific text discussion or description of themselves, a person of their choice, or a hobby they enjoy, even a past holiday or family event, and then allow their creativity to shine in the target language. There are so many possibilities for the use of this web-based program, which is definitely a welcome addition to any lesson plan if teachers want to see their students more engaged with learning English. As a final note on this subject, teachers and students will also enjoy learning this program as it has a very easy learning curve, and is not a difficult procedure to master by any means. A student can have a complete, fully animated, and quite professional-looking presentation ready for viewing in as little as fifteen minutes.

\subsubsection{Suggested Activities regarding the use of Animoto}

To illustrate how Animoto can actually be used for ELT purposes, the following activities are proposed by the authors of this paper:

"During one class period of an EFL reading, writing, or skills class, the teacher will have taken the time to illustrate to the students how Animoto is accessed via the Internet, and how they are to create a free account on the application. This part of the procedure should take no more than approximately ten minutes. After the students demonstrate that 
they are comfortable with the procedure of logging in and creating a new presentation, the teacher can either have the students create a short presentation as part of the class period or give them a homework assignment to create a short presentation to be reviewed in the next class period. The teacher should determine this beforehand, and should inform the students how many points are possible for their participation in, and creation of this asset for the class. The assignment, whether given as an in-class assignment or for homework, can be something the students create which is subject-driven, such as a two-minute presentation about their favorite hobby, a pet, their favorite city, a country vacation spot or their favorite food. Instead of many choices, the teacher could also assign just one subject for the entire class to create their animated slide show on, such as the particular unit of the essentials book or reading text they are studying that week. The students will be given a set of criteria, such as how many pictures or photos they will include in this presentation, for instance a minimum of five photographs or other artwork, and also how many text slides they must include, for example, a minimum of five, including an introduction slide and a conclusion slide. The students must choose a musical piece (provided by the application) and then save and export the file to an MP4 format, or provide the link to their presentation to the teacher. The teacher will then play and review each student's presentations and randomly select four students to present their effort to the class. The other students will also be given the links to each other's presentations, and will be assigned an additional homework assignment which will include a written critique of at least two other students' presentations."

\subsection{Fotobabble}

Fotobabble (http://www.fotobabble.com/register/index) is an important EFL tool because it allows the user to record approximately one minute of their voice and then have the ability to replay that recording and review it, which is a valuable component of EFL teaching and learning. What makes this technology fun for students is the ability to personalize their Fotobabble recordings by uploading a photo or picture, and using the time to describe that photo or tell the listener something interesting about his or her life. For use in the EFL classroom setting, it has endless functions, and many different homework assignment possibilities. One of the greatest advantages of using Fotobabble is that it prepares students to speak out loud in the target language they are learning. This is very difficult for some students to do, especially in the classroom, where there are others. Students who are learning English sometimes feel very shy about their speaking ability, and can be nervous about speaking because of the fear of making a mistake (Kitano, 2001; Gregersen \& Horwitz, 2002), even if their teacher encourages them to make mistakes. It is also not uncommon to have students who absolutely refuse to speak in class, so this particular learning tool lowers the "affective filter" (Krashen \& Terrell, 1995) of students, in that they can be alone and record their voice, their classmates and teacher will not see or hear them during their recording process. Students will have a way to practice and listen to the sound of their voices, and thus become much more at ease communicating in the classroom.

Another feature of Fotobabble is that users can make multiple attempts, practice, and record as much as they want until the recording is perfect. Teachers can assign different speaking projects using Fotobabble each week, and the students can benefit from the process and finally become comfortable speaking in their target language, and will be a much more willing and confident participant in classroom discussions.

\subsubsection{Suggested Activities regarding the use of Fotobabble}

Fotobabble can be primarily used as an EFL homework assignment because it requires the student to record his/her voice, which would be produced more conveniently at students' homes rather than in-class. The following suggested activities into which Fotobabble was incorporated can give an idea about how this tool can be used for ELT purposes.

"During a class period, the teacher can take a portion of that time to demonstrate the login and creation procedure for using Fotobabble, including the uploading of a photo or picture also. Then, the teacher can assign each student in class to team up with a friend or classmate in the same class, and as a homework assignment, they must record five minutes of a conversation between them spoken in the target language. The students will be allowed to create their own script for this conversation, and will be given time to both write the script and practice it during class time, perhaps one class period would suffice for this portion of the activity. The students will be given a due date, such as the next class period in that particular class, or even as far ahead as one week later. This can be determined by the teacher, or can be diplomatically arrived at by the students with the teacher's approval. The student pairs will meet after school and practice their dialogue from the scripts they have written, and when they feel comfortable enough, they can record themselves speaking the dialogue, then save the file and send the link to the teacher. The teacher will choose the best conversation from the ten or twelve assignment submissions, and play that one for the class. The students will be given points for the completion of the assignment according to the teacher's guidelines. This is just 
one of many ideas which will help lower the students' affective filters when speaking the target language, and perhaps in the beginning of their learning period for this application, they will only make individual recordings to help them prepare for eventual pair work using the application."

\subsection{Web 2.0 Tools and Possible Advantages}

In today's world where "young people have been using digital technology from a very early age: desktop and laptop computers, games consoles, mobile/cellular phones and other handheld devices, and all the connectivity of the Internet" (Fee, 2009, p. 2), the Internet has become a turning point in the field of ELT methodology (Warschauer, 2001). Especially the Web 2.0 tools have changed the ways of learning and teaching foreign languages (T1lfarlığlu, 2011).

Web 2.0 is defined by McLoughlin and Lee (2007, p. 665) as "a second generation, or more personalised, communicative form of the World Wide Web that emphasizes active participation, connectivity, collaboration and sharing of knowledge and ideas among users." Some of the Web 2.0 tools that can be integrated into English lessons focusing on teaching four basic language skills and sub-skills such as vocabulary and pronunciation have recently been the topic of some papers. For instance, Başal and Aytan (2014) list Blendspace, Padlet, Scoop.it, Livebinders, Google drive, Vialogues, Voxopop and Lessonwriter as some of the Web 2.0 tools that can be used in the ELT classroom while Kaya (2015) underlines Socrative, Jing, Blogs and Edmodo as beneficial ELT tools.

Web 2.0 tools such as Animoto, Fotobabble, Blogs, Wikis and Edmodo offer many benefits for the field of education in general and for teachers who are seeking ways to extend the learning process outside the classroom (McDougald, 2013). As maintained by Pop (2010), Web 2.0 tools in foreign language instruction cause higher levels of motivation and confidence, which are essential to learn a foreign language. Many researchers have proved that Web 2.0 tools can be used as effective educational tools giving learners a variety of communication and collaboration opportunities (Lee, 2005). It is believed that Web 2.0 tools also have a positive influence on the learning process as they enable learners' self-directed learning (Salaberry, 2001). Learning by means of the Internet is also known to provide more visually enriched course material, appeals to a wider variety of learning styles and contributes to the success in basic foreign language skills (Ghasemi, Hashemi, \& Bardine, 2011).

Since the beginning of the 2000s, the influence of Internet environments on the foreign language learning and teaching process has been found to be positive by many researchers in different research contexts (Arslan \& Şahin-Kızıl, 2010; Monje, 2014; Arani, 2005, Franco, 2008, Ying, 2002, Blake, 2000). For instance, Arslan and Şahin-Kızıl (2010) investigated the use of blogging in their experimental study in which the experimental group was subjected to blog-integrated classroom instruction while the control group was not. They concluded that the group receiving blog-integrated classroom instruction performed better in writing tasks and suggested that blogging has potential to promote more effective writing instruction. In another study, Monje (2014) collected data from a control group who received traditional EFL instruction and an experimental group who were instructed through Web 2.0 based resources (i.e., forums, podcasts, a wiki and a blog etc.). At the end of the experiment, it was found that Web 2.0 tools increased EFL learners' motivation. Investigating the use of blogs as tools to develop learners' reading, writing, and communication skills in English for Specific Purposes (ESP) among EFL learners, Arani (2005) found that weblogs contribute to the improvement of learners' English. Pertaining to another Web 2.0 tool, the Wikis, Franco (2008) incorporated Wikis into the course and revealed that learners not only had positive perceptions about the activities done through wikis but also progressed in terms of the language acquisition process.

In addition to these experimental studies, some researchers explored learners and English teachers' attitudes towards Web 2.0 tools. To illustrate studies dealing with learners' attitudes, Küfi and Özgür (2009) collected data from learners and found that learners had positive attitudes towards the use of interactive web environment in learning English. In another study, Girgin (2011) revealed that learners were pleased with using Web 2.0 tools in their classrooms, but they felt more comfortable with the traditional face-to-face methods of instruction. On the other hand, Yaratan and Kural (2010) concluded that even though teachers generally hold positive attitudes towards technology, their level of technology use in the classroom is below the desired rates because of some limitations such as time constraints. Focusing mainly on wikis, blogs and podcasts, Usluel, Mazman and Arıkan (2009) worked on candidate ELT teachers' awareness about these Web 2.0 tools in Turkey and found that most of the participants were not generally aware of these tools. 


\subsection{Purpose and Research Question}

As can be realized above from the literature review related to the use of web 2.0 tools in ELT, although there have been many studies dealing with different Web 2.0 tools, no studies have focused specifically on EFL teachers' attitudes towards the use of Animoto and Fotobabble in the ELT classroom. Thus, the aim of the current paper is to reveal university level EFL instructors' attitudes towards these tools. As none of the teachers had previously used these tools, they were informed about these tools by means of introductions to both of the tools, tutorials and sample slides. After they became familiar with Animoto and Fotobabble, they were asked to write their reflections on whether these platforms would be good for learning/teaching English and what possibilities or activities could be created using these tools. In line with the purpose of the study, the following research question was posed:

What do EFL teachers who were introduced to Animoto and Fotobabble think about the application of these tools in ELT?

\section{Methodology}

In this study, twelve English teachers (i.e., colleagues with whom the authors are acquainted, thus showed interest in the study and were cooperative in regard to filling out the survey) from three different universities in Turkey were reached through convenience sampling. The teachers who were available and willing to take part in the study during the time of data collection were reached via e-mail with an attached document including an introduction to Animoto and Fotobabble, links to the tutorials about how these tools work as well as links to the sample slides prepared by the writers of this paper (see Figures $1 \& 2$ below).
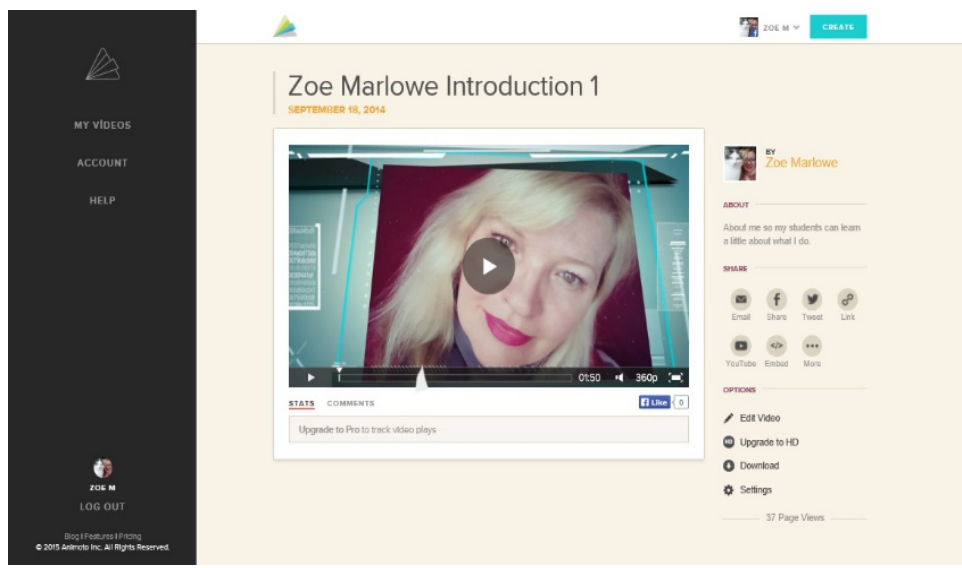

Figure 1. Animoto example:

https://animoto.com/play/vQvdX1jqbkBhHulcbaalaQ
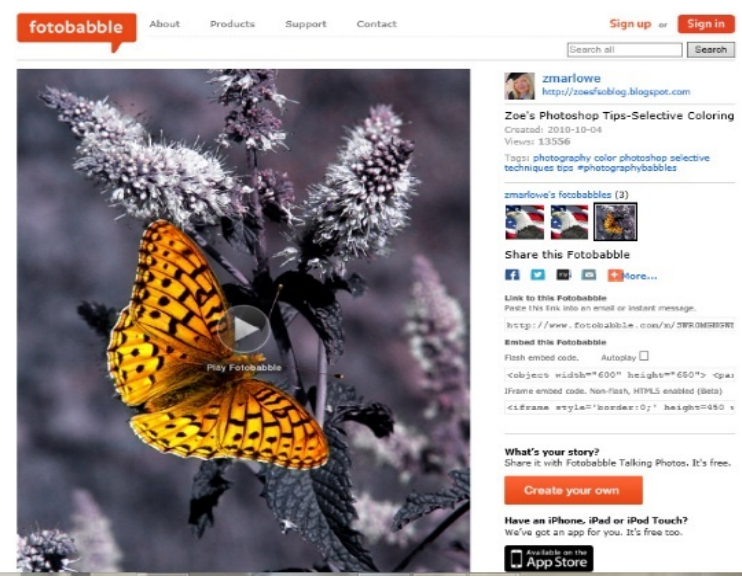

Figure 2. Fotobabble example:

http://www.fotobabble.com/m/SWR0MGNGWERqT2c9 
They were asked to carefully read the introduction and watch the tutorials as well as study the sample slides so that they could have a clear understanding of the tools. At the end of the document, they were asked two questions:

- Do you think these platforms would be good for learning/teaching English? Why/Why not?

- If yes, what possibilities or activities could we use them for in our classes?

Teachers' comments to these questions were subjected to the qualitative content analysis (Miles \& Huberman, 1994), and the data was analyzed below referring to excerpts of the participants.

\section{Results}

Out of twelve instructors who were surveyed, eleven of them wrote positive comments regarding the use of Animoto as both a learning and teaching tool for English language teaching. Ten of the survey participants also viewed Fotobabble positively as well. Only one survey participant wrote a negative comment about Animoto, claiming that it "... is not practical at all. Besides, it is not totally free. There is a 'pro' option on some of the templates which means we can't use all the features free of charge." The vast majority of teachers surveyed appeared to embrace the possibilities of these software packages as useful tools in the teaching of EFL, and shared some ideas about how they would put the software packages to use.

Suggestions by one teacher included: "These are good platforms to use for portfolio homework, and would be enjoyable applications to use." The same teacher also wrote about the practical use of Animoto as a personal introduction tool, stating: "I think it can be good for a teacher to introduce herself/himself to her/his class at the beginning of the year. It is more interesting and creative than just entering in a classroom and talking about yourself in front of the students." The teacher also noted: "Students' expectations and anticipations about the English class they will attend will be positively affected."

Another teacher made the following remarks about Animoto: "If it is not hard to use, you probably will go on dealing with it. If learners go on using it, they will sign in and practice more often. After a while, they will learn more things in English." The teacher also made another point: "When users share something that they have via these sites, they utilize their English. For them, the aim is not to practice English, but to use it as a tool to share something on these sites. So, users can practice English unconsciously, and I think after a while they will recognize their improvement in English." The same teacher also commented on several Fotobabble attributes: "Fotobabble.com recordings can be helpful for users. When students who study English at school upload their voice and listen to it, they can notice their pronunciation mistakes." "Replaying and reviewing allows them to see the points that they need to practice more. Then, they can study the pronunciation of these words and upload the video again so they can improve their speaking abilities."

One of the teachers also noted: "The teacher may require the students to create a short visual homework on a given topic and record their voice. Then, the teacher can analyze the vocabulary and pronunciation mistakes and share them in class or he/she can talk about the mistakes with the students in his/her office privately. Moreover, the teacher can permit students to listen to each homework in class and take notes about the mistakes they hear. During the lesson, they can share and correct them, so this will be helpful for both the student who prepares the homework and students who deal with the editing process."

Another teacher suggested using the software for non-classroom activities: "They can be used for out of class activities such as discussions about presentations, and writing feedback and commenting about students' own work etc." Comments about both software applications from another teacher: "They would be good for learning English; for example, our students can watch a video of us via Animoto and learn new things such as new vocabulary from us. Also they can improve their English by watching videos of native speakers. As time goes by, our students' listening skills will improve. Secondly, our students can listen to us and native speakers via Fotobabble. Then they can record their voices and check their pronunciation. In short, both platforms are useful for learning English."

One of the teachers suggested a different use for Animoto in particular: "They can create animations by uploading their pictures and practicing the topics covered in the class." In addition, one of the teachers shared an idea for using the software in conjunction with other social networking software, and even described a point-value system for grading their use of the tools: "For example, our students can watch their own videos and write a comment about them on a Twitter group and in this way can evaluate their comments. If a student doesn't write any comments, the student will get zero points. If a student writes comments about all the videos, then the student will get full points."

In contrast to the majority, two of the survey participants wrote negative comments about the Fotobabble software, stating such points as: "I don't think Fotobabble is useful for teachers. It can take too much time to prepare a slide by 
using it. Recording something again and again takes time." And another teacher stated: "Fotobabble is not very beneficial for the language learners, either. It looks very time consuming to prepare a slide using it. Also, allocated recording time is too short. Moreover, the quality of the recording may be very bad depending of the hardware of your computer." This comment articulated the same point as the first negative comment regarding the time it takes to prepare a slide.

As stated earlier, the majority of the surveyed teachers showed marked enthusiasm for the use of the target tools discussed in this study, and very little opposition to using them was given as a response by the majority.

\section{Discussion}

Using technology to augment their lesson plans is what innovative EFL teachers must do in order to keep their students focused on and more engaged with learning the target language. Many simple-to-operate Internet-based tools are available to teachers and students who are willing to use them in the EFL classroom setting, and can be included along with the usual book-based curriculum as an integral part of the English teaching and learning process.

Although there have been many studies dealing with different Web 2.0 tools, no studies focusing on English teachers' attitudes towards the use of Animoto and Fotobabble in the ELT classroom have so far been carried out. Therefore, in this paper, considering the importance of teachers and students' positive attitudes for the success of technology integration (O'Conner \& Gatton, 2003), the use of Animoto and Fotobabble in ELT was discussed from the perspective of twelve university EFL teacher teaching at three different universities in Turkey. The motivation for this study lies under the fact that teachers' tendency to use a software tool has a positive effect on their attitudes towards the acceptance of technology while teaching (Sepehr \& Harris, 1995; Handal, 2004; Albirini, 2006).

The participants were reached via e-mail including a document introducing these two platforms, tutorials and links to sample slides. At the end of the document, they were asked two questions (see Methodology section). Their ideas about these questions were analyzed, and their opinions about the platforms were exemplified referring to their comments. According to the results, although there were a few people who did not acknowledge the value of these technologies, the majority of the instructors expressed their positive attitudes towards Animoto and Fotobabble which are believed to lead to learner-centered and constructivist environments, social interactions, and active and social learning (Ferdig, 2007), and gave numerous examples supporting the use of these tools in the ELT classroom.

Many instructors held the idea that these two Internet tools could be used to assign students' portfolio homework and animations by uploading their pictures and voices. It was also argued by some teachers that these tools can motivate students to learn the language and can be used to help students practice different language skills. The positive comments made by the participants corroborate with the arguments underlined in the literature dealing with the use of Web 2.0 tools to teach a foreign language. For instance, it is believed that Internet tools enable the contribution of the learning process outside of the classroom (McDougald, 2013), lead to higher levels of confidence and motivation (Pop, 2010), offer a variety of collaboration and communication alternatives (Lee, 2005), and help learners succeed in mastering the basic foreign language skills (Ghasemi, Hashemi, \& Bardine, 2011). Considering that the acceptance and implementation of new technologies are strongly influenced by the teachers' attitudes (van Braak, Tondeur, \& Valcke, 2004), positive comments by the participants in this study can be regarded as promising for the use of Animoto and Fotobabble in the ELT classroom.

As for negative comments, it can be concluded that only one instructor was opposed to the idea of using Animoto in ELT by indicating that the platform is not completely free. While this participant may have a solid point about the cost to upgrade Animoto in order to utilize the more advanced features, there are still plenty of features available to the users who just use the completely free version. Two other instructors were against the use of Fotobabble arguing that it might take too much time to prepare a slide using this platform and the given recording time in Fotobabble is too short. However, both of these survey participants appear to have possibly misunderstood the use of Fotobabble, as it is meant for the students to record their own voices, so a 'slide preparation' is not necessary because the students can easily understand how to use the software by reading the instructions online, and the recording time is adjustable, allowing up to five minutes of recording time for the user. It is recommendable that for those teachers having negative attitudes towards such platforms, there is a need for professional development in the way of in-service training or a specialized course for teachers (Cooke-Plagwitz, 2005; Hong, 2010; Hişmanoğlu, 2010; Sarıçoban, 2013), which is believed to contribute to their positive perceptions of Internet tools and make them not only aware of but also confident about using technology in their classrooms.

It would be fair to suggest that using the tools discussed in this paper will help students to participate in meaning-making processes and use their creativity, as well as dramatically lower their "affective filter" (Krashen \& 
Terrell, 1995) for speaking in their target language, which is vitally important in language acquisition. The majority of teachers who were surveyed found value in the software tools, and as evidenced in the discussion of survey results, began to formulate creative ideas as to how they would use them for their classes. A quote from one of the survey participants sums it up: "With the use of these sites in the teaching process, learners' motivation will increase, they will focus on the lesson, and of course with this motivation and enthusiasm they will learn more."

\subsection{Conclusion}

It has been illustrated in this paper that Animoto and Fotobabble are useful for the teaching and learning EFL. Their uses are practically limitless depending on the teachers and the students' creative ideas on how to implement them into the English learning curriculum. The survey participants gave overall positive remarks along with some creative possibilities for the use of these web-based programs.

The authors of this paper realize the importance of using technology in teaching, especially with regard to incorporating Internet tools which will enhance the teaching processes, and also the learning experiences of the students, who in this day and age are exposed daily to the latest in computer technology. If teachers desire to keep their students engaged and interested in their English lessons, it seems appropriate to include Animoto and Fotobabble as fun and functional tools for expanding and enhancing the learning opportunities in their classrooms.

In conclusion, it is recommended that further studies be conducted on this topic, using larger data collections, quantitative and qualitative survey instruments and other Web 2.0 software applications. It is also known that different groups of individuals have different degrees of access to technology (Dutton, 2004). Therefore, different study groups such as students at different levels of education and K-12 teachers can be involved in future studies.

\section{References}

Albirini, A. A. (2006). Teacher's attitudes toward information and communication technologies: The case of Syrian EFL teachers. Journal of Computers and Education, 47, 373-398. http://dx.doi.org/10.1016/j.compedu.2004.10.013

Arani, J.A. (2005). Teaching writing and reading English in ESP through a web-based communicative medium: Weblog. ESP-World, 4(3).

Arslan, R. Ş., \& Şahin-Kızıl, A. (2010). How can the use of blog software facilitate the writing process of English language learners? Computer Assisted Language Learning, 23(3), 183-197. http://dx.doi.org/10.1080/09588221.2010.486575

Başal, A., \& Aytan, T. (2014). Using Web 2.0 tools in English language teaching. ICT for language learning, 7th Edition, Pixel. Retrieved from http://conference.pixelonline.net/ICT4LL/files/ict411/ed0007/FP/1314-ICL807-FP-ICT4LL7.pdf

Blake, R. (2000). Computer mediated communication. A window on L2 Spanish interlanguage. Language Learning \& Technology, 4(1), 120-136.

Cooke-Plagwitz, J. (2005). Adventures in teaching: Helping language teachers discover the joy of teaching with technology. The International Association for Language Learning Technologies Journal of Language Learning Technologies, 37(1), 35-40.

Dutton, W. H. (2004). Social transformation in an information society: Rethinking access to you and the world. Paris: UNESCO.

Fee, K. (2009). Delivering E-learning, Kogan Page, London.

Ferdig, R. E. (2007). Editorial: Examining social software in teacher. Journal of Technology \& Teacher Education, 15(1), 5-10.

Franco, C.D.P. (2008). Using wiki-based peer-correction to develop writing skills of Brazilian EFL learners. Novitas-ROYAL, 2(1), 49-59. Retrieved from http://www.novitasroyal.org/franco.pdf

Ghasemi, B., Hashemi, M., \& Haghighi Bardine, S. (2011). The capabilities of computers for language learning. Procedia-Social and Behavioral Sciences, 58, 28-52. http://dx.doi.org/10.1016/j.sbspro.2011.11.012

Girgin, E.G. (2011). A web 2.0 tool for language teaching with flash content. Procedia Computer Science, 3, 627 631. http://dx.doi.org/10.1016/j.procs.2010.12.105 
Gregersen, T., \& Horwitz, E. K. (2002). Language learning and perfectionism: Anxious and non-anxious language learners' reactions to their own oral performance. The Modern Language Journal, 86(4), 562-570. http://dx.doi.org/10.1111/1540-4781.00161

Handal, B. (2004). Teachers' instructional beliefs about integrating educational technology. E-Journal of Instructional Science and Technology, 17. Retrieved from http://www.usq.edu.au/electpub/e jist/docs/Vol7_No1/Commentary/.Teachers_ins_beliefs.htm.

Hişmanoğlu, S. (2010). Attitudes of L2 teachers towards internet-based foreign language teaching. Procedia Social and Behavioral Sciences, 3, 106-111. http://dx.doi.org/10.1016/j.sbspro.2010.07.019

Hong, H. (2010). CALL teacher education as an impetus for L2 teachers in integrating technology. ReCALL, 22(1), 53-69. http://dx.doi.org/10.1017/S095834400999019X

Hubbard, P. (2009). General introduction. In P. Hubbard (ed.), Computer assisted language learning: Foundations of CALL. Critical concepts in linguistics (vol. 1). (pp. 1-20). New York: Routledge.

İrgin, P., \& Turgut, Y. (2009). Using Animoto for language education. The International Journal of Learning, 16(9),1-8.

Kaya, H. (2015). Blending Technology with Constructivism: Implications for an ELT Classroom. Teaching English with Technology, 15(1), 3-13.

Kern, R. G. (2006). Perspectives on technology in learning and teaching languages. TESOL Quarterly, 40(1), 183-210. http://dx.doi.org/10.2307/40264516

Kitano, K. (2001). Anxiety in the college Japanese language classroom. The Modern Language Journal, 85, 549-566. http://dx.doi.org/ 10.1111/0026-7902.00125

Krashen, S., \& Terrell, T. (1995). The natural approach: Language acquisition in the classroom. Hertfordshire, Prentice Hall.

Küfi, E.O., \& Özgür, B. (2009). Web 2.0 in learning English: The student perspective. Procedia-Social and Behavioral Sciences, 1(1), 326-330. http://dx.doi.org/10.1016/j.sbspro.2009.01.061

Lee, L. (2005). Using Web-based instruction to promote active learning: Learners' Perspectives. CALICO Journal 23(1), 139-156.

Light, D., \& Keisch Polin, D. (2010). Integrating Web 2.0 tools into the classroom: Changing the culture of learning. EDC Centre for Children and Technology. New York. Retrieved from http://files.eric.ed.gov/fulltext/ED543171.pdf

McDougald, J.S. (2013). The use of new technologies among in-service Colombian ELT teachers. Colombian Applied Linguistics Journal, 15(2), 247-264.

McLoughlin, C. \& Lee, M. J. W. (2007). Social software and participatory learning: Pedagogical choices with technology affordances in the web 2.0 era. Proceedings Ascilite Singapore.

Miles, M. B., \& Huberman, A. M. (1994). Qualitative data analysis. Thousand Oaks, CA: Sage.

Monje, E. M. (2014). Integration of Web 2.0 tools in a VLE to Improve the EFL Spanish university entrance examination results: A quasi-experimental study, CALICO Journal, 31(1), 40-56. http://dx.doi.org/10.11139/cj.31.1.40-56

Morgan, M. (2008). More productive use of technology in the ESL/EFL classroom. The Internet TESL Journal, 14(7). Retrieved from http://iteslj.org/Articles/Morgan-Technology.html.

O'Conner, P., \& Gatton, W. (2003). Implementing multimedia in a university EFL program: A case study in CALL. In S. Fotos, \& C. M. Browne (Eds.), New perspectives on call for second language classrooms (pp. 199-224). Mahwah, NJ: Lawrence Erlbaum Associates

Prensky, M. (2001). Digital natives, digital immigrants. On the Horizon, 9(5), 1-6. http://dx.doi.org/10.1108/10748120110424843

Pop, A. (2010). The impact of the new technologies in foreign language instruction our experience. Procedia Social and Behavioral Sciences, 2, 1185-1189. http://dx.doi.org/10.1016/j.sbspro.2010.03.169

Salaberry, M. R. (2001). The use of technology for second language learning and teaching: A retrospective. Modern Language Journal, 85(1), 39. http://dx.doi.org/10.1111/0026-7902.00096 
Sarıçoban, A. (2013). Pre-service ELT teachers' attitudes towards computer use: A Turkish survey. Eurasian Journal of Educational Research, 53, 59-78.

Sepehr, H. \& Harris, D. (1995) Teachers' use of software for pupils with specific learning difficulties. Journal of Computer Assisted Learning, 11, 64-71. http://dx.doi.org/10.1111/j.1365-2729.1995.tb00118.x

Shyamlee, S., \& Phil, M. (2012). Use of technology in English language teaching and learning: An analysis. Paper presented at the International Conference on Language, Medias and Culture IPEDR, IACSIT Press, Singapore.

Tilfarlığlu, F. Y. (2011). An international dimension of the student's attitudes towards the use of English in web 2.0 technology. Turkish Online Journal of Educational Technology, 10(3), 63-68.

Usluel, Y.K., Mazman, S.G., Arıkan, A. (2009, November). Prospective teachers' awareness of collaborative web 2.0 tools. Paper presented at the IADIS International Conference WWW/Internet, Rome, Italy.

van Braak, J., Tondeur, J., \& Valcke, M. (2004). Explaining different types of computer use among primary school teachers. European Journal of Psychology of Education, 19(4), 407-422. http://dx.doi.org/10.1007/BF03173218

Warschauer, M. (2001). Millennialism and media: Language, literacy, and technology in the 21 st century. AILA Review, 14, 49-59.

Yaratan, H., \& Kural, C. (2010). Middle school English language teachers' perceptions of instructional technology implementation in North Cyprus. Turkish Online Journal of Educational Technology, 9(2), 161-174.

Ying, F. (2002). Promoting learner autonomy through CALL projects in China's EFL context. Teaching English with Technology, 2(5). 